\title{
ENHANCING LEARNER ACHIEVEMENT THROUGH PROFESSIONAL DEVELOPMENT: THE ZIMBABWEAN EXPERIENCE
}

\author{
G. N. Shava \\ Post-doctoral research fellow \\ University of the North West \\ Potchefstroom, South Africa \\ e-mail: gnshava@gmail.com
}

\section{ABSTRACT}

In this article I argue that effective professional training in higher education has emerged as a major strategy for enhancing learner achievement in rapidly changing higher education teaching and learning environments. The changing context of higher education teaching in Africa presents new challenges for academics, and professional development is accepted as an effective means of addressing them. In-depth professional development in universities is essential for providing academics with the skills and knowledge they require in order to improve their pedagogical skills. Consequently, the goal of this qualitative case study was to understand the extent to which a professional development programme at a university in Zimbabwe has enhanced the performance of academics. By means of in-depth, semi-structured interviews, ten academics from the university discussed their experiences of participating in a professional development course. The findings revealed that although they were excited by the professional development programme, which was intended to enhance the quality of their teaching, and although they believed that students benefitted from their enhanced teaching, they felt overwhelmed by the demands of engaging in a formal course.

Keywords: academic development, higher education, learner achievement, professional development, universities.

\section{INTRODUCTION}

Unlike South Africa, Namibia and Lesotho, limited research has been conducted in Zimbabwe to examine the professional development experiences of academics in higher education institutions (Mukeredzi 2013). In universities across the world, professional development has proved a vital strategy for enhancing student achievement. Professional development, according to Candy (1996), Gosling and O’Connor (2006), Guskey (2002) and Mukeredzi (2013) is taken to mean practices designed to enhance the academic performance of an institution of higher education. The professional development of academics generally focuses on enhancing the professional competence of faculty members by giving them input on policies governing the design, delivery, evaluation and recognition of teaching. Professional 
development is also concerned with educational development, which includes curriculum development and instructional design. Aside from benefits to the students, formal professional development programmes provide academics with job satisfaction (Guskey 2002) and help to build the competencies and motivation of academics to teach, conduct research and engage in community service.

Professional development is imperative for the currency and relevance of a proficient teaching workforce in higher education and to maintain the quality of teaching (Guskey 2000; Higgins and Harreveld 2013; Hunzicker2011; Hossain 2010; Rust 2000). However, pedagogical skills and the other competencies needed in the changing context of higher education cannot be addressed only through short courses at departmental and faculty levels (Gosling 2008). More formal, comprehensive and integrated models of professional development, like the Post-graduate Diploma in Higher Education (PGDHE) have been shown to have a greater influence on developing pedagogical skills for academic staff (Mukeredzi 2013). Stefani and Elton (2002) demonstrate that as a result of the increasing prominence and support for learning and teaching enhancement programmes in many countries, the quality of teaching in higher education has improved greatly. Stefani and Elton (2002) confirm that higher education teachers who have undergone some form of professional development in their teaching role do a better job than those who have not.

Driven by a variety of perceived social, cultural and economic imperatives, professional development programmes have become an important focus for African governments. In the context of increasing economic constraints and the recognition that students in the twenty-first century have a right to quality educational experiences, higher education institutions in Africa are examining strategies to enhance the quality of teaching and learning experiences (Guskey 2000; Hunziker 2011; McWilliam 2002). The result, especially in South Africa, has been a proliferation of formal professional development programmes, such as the PGDHE offered to academics. Universities in Namibia, Lesotho and Zimbabwe have followed suit. According to some researchers (Eley 2006; Gibbs and Coffey 2004; Gosling 2001; 2008; Ling 2009), professional development interventions for academics ultimately lead to improved learning. There is also general agreement that university professional development programmes have a positive impact on academics' pedagogical practices and students' learning outcomes. In Zimbabwe, universities such as the University of Zimbabwe, Midlands State University and the National University of Science and Technology have established professional development courses through their education faculties.

This article provides insights into the professional development experiences of academics 
at the National University of Science and Technology (NUST) in Zimbabwe, who are involved in the PGDHE. Some of the success stories associated with the University's formal professional development strategy are also examined. The aim of the study is to explore the role of professional development in enhancing the teaching competencies of academics, with specific reference to a Zimbabwean context.

The research is presented in four sections. The first section provides a brief review of literature and theoretical frameworks on professional development; the second section describes the research design of a recent study exploring the experiences of academics who participated in the PGDHE programme. The third section presents findings regarding professional development as a strategy to enhance teaching and learning at the University. The fourth section contains suggestions for providing effective professional development.

\section{AN EMPIRICAL BASIS FOR THE IMPORTANCE OF PROFESSIONAL DEVELOPMENT IN HIGHER EDUCATION INSTITUTIONS}

In contrast to South Africa, so few studies are conducted in Zimbabwe that focus specifically on professional development of academics in higher education institutions, so an examination of their effectiveness is timely. In Zimbabwe, and probably in the entire SADC region, there is currently no professional requirement for teaching in higher education institutions. The majority of academics in universities and colleges do not have teaching qualifications, so they need to learn on the job. This is also true of academics teaching in colleges of education.

In striving for a threshold level of quality assurance, many Australian universities now require academic staff new to teaching to undertake an initial teacher preparation programme in the first years of their appointment (Eley 2006) and encourage academics to participate regularly, throughout their careers, in professional development related to teaching (Gibbs and Coffey 2004; Gosling and O’Connor 2006; Meirs and Ingvarson 2003; Kreber and Brook 2001). Universities in Sweden, Norway, the United States, Malaysia and Sri Lanka have made pedagogical training of university teachers compulsory as a step towards assuring the quality of teaching (Ballantyne, Bain and Packer 1999; Moon 2004; Roxå and Mårtensson 2008).

In Zimbabwe, the attainment of the PGDHE enhances the promotion prospects of the academic. The PGDHE is accredited by the Ministry of Higher Education in addition to its institutional accreditation. Professional training is required in order to meet the challenges and changes that constantly face staff in institutions of higher education. These include continual changes in subject content, the emergence of new instructional methods, advances in technology and changing laws and procedures (Doherty 2010; Gibbs and Coffey 2004; Guskey 
2000; Hunziker 2011), as well as the general learning requirements for higher education. There is an assumption (Barnard et al. 2011; Cox and Richlin 2004; Hossain 2010) that professional development practices increase students' achievement; however, both Hunzicker (2011) and Yoon et al. (2007) suggest that further research is needed to substantiate any causal links in this area. Recent studies have established a direct relationship between professional development programmes for academics and students' learning outcomes (Doherty 2010; Hossain 2010; Hunzicker 2011; Chalmers and Gardiner 2015).

In summary, in an increasingly challenging teaching environment in higher education institutions the world over, the importance of professional development is crucial and significant in improving teaching competences.

\section{THEORETICAL FRAMEWORK}

It is generally believed that high-quality professional development grounds academics in both pedagogy and content, offers them opportunities to practise new ideas in similar contexts, is sustained over time and offers a community of peers and coaches that provide support and opportunities for collaboration and provides rich resources. Borko (2004), Loucks-Horsley, Love, Stiles, Mundry and Hewson (2003), McLaughlin and Talbert (2006), and Weiss and Pasley (2006) emphasise the developmental nature of professional development, as compared with the short-workshop model that has dominated the field in the past. In other words, professional development is valued as a powerful change agent for total institutional reform and improvement (Borko 2004). Guskey (1986) has advanced the idea of evaluating the importance of professional development by its ultimate impact on students.

Guskey (1986; 1997) presented a model for professional development programmes in which it is viewed as a process linking changes in classroom practices. Furthermore, staff development programmes should result in changes in teaching approaches and achievement by learners. The process of professional development involves the academic acquiring knowledge and competences that leads to improved teaching. Improved teaching should lead to success and achievement by students. This approach views the professional development programme as the initial triggering mechanism in the change process of an academic. It also recognises that the student learning outcomes, which are foregrounded by academics once they have transformed their classroom practices, shape academics' beliefs and attitudes in relation to their teaching practice.

Figure 1 shows the professional development model, as formulated by Guskey (1986). 


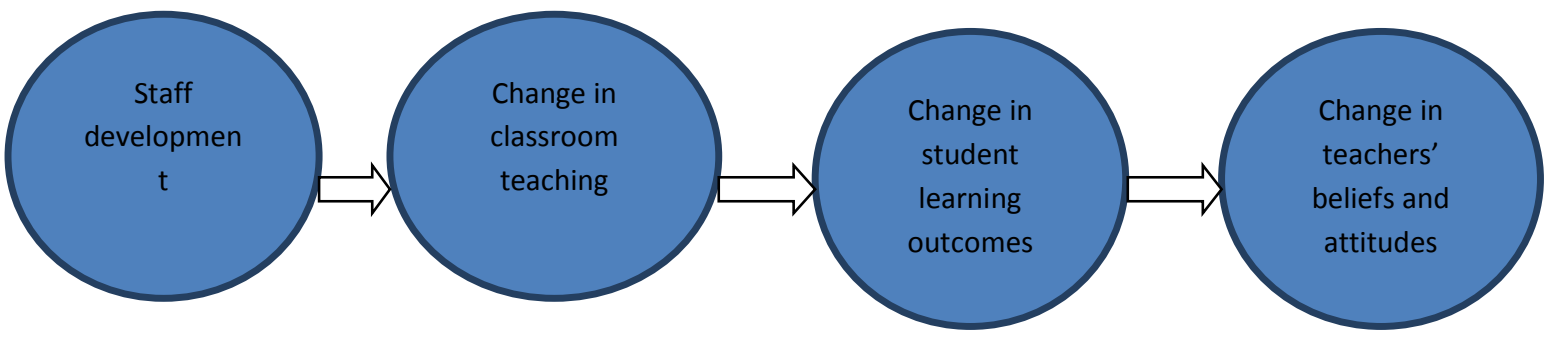

Figure 1: A model of the process of teacher change (Guskey 1986)

This framework by Guskey (1986) emphasises the continuous implementation of professional development to get the desired change in classroom practices, which will enhance learner achievement and finally change academic's beliefs and attitudes towards teaching. At the centre of this framework is the ultimate goal of student learning outcomes.

\section{SETTING FOR THE STUDY AT THE NATIONAL UNIVERSITY OF SCIENCE AND TECHNOLOGY}

Participants on the PGDHE had to complete twelve modules in total. Six modules were compulsory, while the remaining six could be selected from a choice of ten elective modules. Each semester consisted of three core and three elective modules. All the courses were assessed through course-work only. For each module, participants attended a four-hour contact session. After each contact session, participants engaged in independent reading and completed a series of assignments. As part of each module, course tutors conducted classroom observations to assess the candidates' teaching. All the modules aimed to expose academics to key issues and theories, as well as a wide range of practical learning and teaching methods, including the use of relevant technologies that would help their students learn more effectively (see Appendix 1 for an outline of the modules of the PGDHE).

\section{RESEARCH DESIGN AND METHODOLOGY}

Keeping in mind the arguments for professional development for academics, I designed a case study to explore the experiences of academics at NUST. My aim was to arrive at a better understanding of their perceptions and enactments of professional development as a strategy to improve teaching and learning in higher education. Case studies of professional development (Firestone and Riehl 2005; Patton 2001; Silverman 2014) are able to capture the thinking (Charmaz 2006; Creswell 2007; Morse 1991) and actions of academics within their contexts (Bernard 2002; Stake 2005).

The purpose of the study was also to examine the perceptions of academics participating 
in professional development, and the effects of their learning on their teaching practice and on their students' learning. Ultimately, I was interested in whether individuals were able to improve their teaching as a result of participating in the PGDHE, and if so, in what way(s).

\section{RESEARCH QUESTIONS AND OBJECTIVES}

The study attempted to answer the following questions:

(1) What are the perceptions of participants in relation to professional development offered through the PGDHE?

(2) In what ways does professional development enhance the teaching competences of academics?

(3) What is the level of support for colleagues' participation?

In particular, the study aimed to:

- understand the opinions of participants regarding the value of the PGDHE offered at the university

- $\quad$ establish whether or not there were changes in participants' teaching approaches and student learning after participating in the programme

- understand the level of support for colleagues' participation in the PGDHE offered at the university.

\section{DATA GENERATION}

In this qualitative study, I examined the experiences of ten academics from a possible 200 who had successfully completed the PGDHE. The ten participants who were interviewed were all between the ages of 25 and 49, and taught a range of different disciplines including Applied Science, Library and Information Technology, Commerce, the Built Environment, and Medicine.

Data were collected through semi-structured, open-ended interviews, each lasting between one hour and an hour and a half.

The fact that participants were academics who had participated in the PGDHE course allowed for a tentative generalisation of findings with regard to the effectiveness of the PGDHE offered by the University. In addition, findings from the study could contribute to the expansion of knowledge about professional development. 


\section{DATA ANALYSIS}

I made sense of the data through an inductive process (Gay, Mills and Airasia 2012) of progressively grouping a large set of specific cases according to common themes that emerged. I reflected on how the data explained and enhanced the conceptualisation of professional development for academics, for example, by asking analytical questions such as 'What perspectives does this participant hold in relation to professional development for academics?' and 'How beneficial are professional development programmes offered by the University?' The data analysis of ten participants yielded several key themes, which are discussed below.

\section{DISCUSSION OF RESULTS}

The significant role played by professional development in enhancing the quality of teaching and learning was highlighted in various literature sources on professional development of academics (Higgins and Harreveld 2013; Hossain 2010; Hunzicker 2011; Meiers and Ingvarson 2003; Moon 2004; Roxå and Mårtensson 2008). Comments made by participants in this study were largely in keeping with the literature on the topic, since participants in this study noted that the PGDHE has the potential to enhance the quality of teaching and learning. Findings from the study will now be discussed briefly.

\section{ATTITUDES OF ACADEMIC MEMBERS TO PROFESSIONAL DEVELOPMENT}

The ten interviewees reported that their departments were supportive of their participation in the PGDHE. One of the participants remarked that:

There is positive encouragement by the department especially our chairperson who also did the programme with the first intake. My teaching time table was adjusted to facilitate my attendance and follow up study. I have been nominated to lead the department on teaching and learning. I am given sessions in the department meetings to highlight on methods of teaching in higher learning institutions. (Participant 2)

Another participant commented:

In one of our departmental meetings our chairperson encouraged members to join the PGDHE offered by the university through the faculty of Science and Technology Education, saying the programme will improve your skills in teaching especially assessment of learning said our chairperson. (Participant 4)

When asked to expand on the levels of support participants got from their leadership, the interviewees indicated that the PGDHE was well supported by the University management and 
their supervisors. In particular, they mentioned the following indications of support:

- Members of NUST staff did not pay tuition for participating in the programme unless they failed a course.

- The Promotions Committees considered the PGDHE when deciding on tenure and promotion for staff members.

- $\quad$ Teaching timetables were adjusted to accommodate participation in the programme.

- $\quad$ Academics were given opportunities to give feedback to their colleagues on what they had learnt from the programme.

- Chairpersons also motivated successful staff members by highlighting and acknowledging their successes.

- Chairpersons also highlighted the importance of the programme, especially for newly appointed academics and those who did not have teaching backgrounds.

- $\quad$ Excellent teaching practices were recognised and rewarded.

- $\quad$ Resources were made available for those participating in the PGDHE programme.

While the majority of the participants indicated that the PGDHE was well supported by academics, one participant noted:

The programme is good. Hey, but I tell you I completed the hard way, the course is too demanding, my chairperson was encouraging but at the same time she could say that students should not suffer as a result of my participation in the programme. There is too much work, at one stage I discovered that the night was very short when I spent the whole night writing an assignment. The assignments in most cases are just too long such that the whole year one will focus on the programme. I support the programme but something should be done about the workloads, our universities are involved in multiple games, with competing goals and different rules. They want us to publish for promotion, they want us to learn, they also want us to teach, income generating, they want quality which is which? (Participant 6)

Given the responses from participants, professional development programmes are gaining support, in particular from the University management and participants in the programme. Generally, the PGDHE programme at NUST currently receive positive support from management of the University. There is a feeling that the provision of such a programme by the University provides basic pedagogical competencies among academics, which will impact favourably on student learning outcomes. 


\section{PERCEPTIONS OF THE ROLE OF PGDHE IN IMPROVING TEACHING}

An important finding was that the participants thought that the PGDHE had improved their teaching competencies. Eight participants responded positively to a question about whether they had changed their approaches to teaching as a result of participating in the PGDHE. They acknowledged that participating in the programme was of benefit to their learners. Some of the changes noted were the more frequent use of group work, a clear focus on student learning outcomes in the preparation of lectures, less prescriptive teaching approaches and improved assessment processes. Participant 5 also mentioned having more respect and empathy for students and experiencing greater levels of student participation in class. The same participant felt that her teaching has changed for the better, and reflected as follows:

A lot has changed in my teaching. I used to dominate lessons, I also used to talk and talk during my lecturers but now I have realized that I should let the learners talk more than I do. (Participant 5)

Participant 7 commented,

The PGDHE greatly improved or I can say greatly influenced my current teaching methods and approaches.

She identified improvements in the quality of her teaching skills and strategies and acknowledged that these were gained from her participation in the PGDHE. According to Participants 5, 6 and 7, the PGDHE has resulted in them adopting new teaching approaches. In addition, they received valuable feedback from peers and tutors on the PGDHE about teachingand learning-related issues. One of the participants noted:

I have not received any training from my department on how to teach especially using online delivery presentation. My teaching has greatly improved, my teaching is now more learner oriented, using a wider range of teaching methods I learnt from the PGDHE programme. I have greatly become a better planner of my work, I can constantly reflect on my practices and using different approaches or methods of teaching. (Participant 4)

Another participant commented:

In my teaching before, I never thought of group activities, I never thought of student learning outcomes. My student work assessment has greatly improved, I am more respectful to my students, I now allow greater participation from students during lesson delivery. In short my teaching approaches have greatly improved as a result of my participation in the PGDHE. My students now enjoy my lessons, they even do some demonstrations in class, I share ideas with my learners. I was surprised they nickname me the 'quality guru'. This is as a result of the motivation they have in my lessons. (Participant 6) 
Participants noted the following as evidence of improvements in their teaching:

- Increased confidence in lesson delivery

- Improved assessment and questioning techniques

- $\quad$ Learning of new teaching methods, e.g. online teaching

- Designing and developing courses

- $\quad$ More learner-centered approaches to teaching

- Improved questioning techniques during lessons

- $\quad$ Motivating students

- $\quad$ Allowing students to demonstrate to their peers

- $\quad$ Participatory methods of teaching, e.g. group work

- $\quad$ More participation by students

- $\quad$ Learner-dominated activities in class.

These responses were summarised thus by one of the participants:

I used to talk and talk the whole day. I have realised that in teaching practical subjects like computer science the teacher should stop talking and let the learners learn. I used to dominate my lessons and at the end of the day they could not understand, I am now a powerful computer science lecturer as a result of my participation in the PGDHE. Learners quickly grasp as a result of my new approaches. I even give those with an idea to demonstrate to others, some students know quite a lot. (Participant 1)

Responses from the majority of participants suggested that professional development for academics enabled the development of skills, knowledge and attitudes within their respective teaching areas. However, two of the participants believed that the course had not improved or changed their teaching. Participant 8, for example, remarked that:

I was using PowerPoint presentation and nothing has changed much. Not much has changed in as far as my teaching is concerned, well I have improved, but I don't think I have typical examples of the changes. (Participant 8)

Participant 8 also said:

Eh--- I am not sure whether my teaching has greatly changed, yes I have improved here and there but basically students we have are weak. Learners cannot communicate I don't know why. Let me see if there are some improvements at the moment I cannot tell. (Participant 8) 
Although Participant 8 did not agree that the course significantly improved his teaching, there was a general consensus that the PGDHE programme had sharpened the teaching skills of most participants. Comments from the majority of participants indicated that professional development programmes empowered them, and contributed to improved teaching and the spreading of good practice. This is in accordance with findings in the literature (Chalmers and Gardiner 2015; Hossain 2010; Hunzicker 2011).

According to Kreber and Brook (2010), the professional development of academics improves learning outcomes for students and thus has benefits for employers, for society and for the economy. I would argue that, in an increasingly changing higher education environment, the professional development of academics' pedagogical skills is crucial. Academics find a wide range of strategies useful in developing their professional expertise as a result of sharing of ideas by participants in professional development programmes. Participant 3 stated that,

The PGDHE is important to me this is a programme that has greatly improved my teaching skills especially on student assessment I have greatly changed.

Kreber and Brook (2001) showed that professional development in higher education institutions improves learning outcomes for students, and indirectly benefits employers and society.

Thus the majority of participants valued the teaching and learning processes undertaken in the PGDHE.

\section{BENEFITS OF THE PGDHE TO THE UNIVERSITY DEPARTMENTS}

A number of participants (2, 3 and 5 ) responded positively to the question on whether their participation in the PGDHE was of benefit to the departments. Participant 3 said:

Yes, we are taking the lead in co-coordinating teaching and learning committees in our departments.

This is an indication that participants of the PGDHE had increased opportunities to undertake other responsibilities in the University; these responsibilities were an essential element in the promotion of academics. Participant 4 noted that her participation in the PGDHE had increased her ability to communicate with colleagues on issues related to teaching and learning, and that s/he was able to make a significant contribution in such interactions.

There was evidence that participants in the PGDHE had also developed deeper knowledge and understanding of course design, which to a great extent benefited the department or the university at large. The most important benefit identified by participants was the innovations in 
curriculum or classroom-focused changes, including the development of skills required for effective teaching in their departments. These these developments had an impact on organisational effectiveness and helped develop a work environment that could stimulate continuous improvements. This was an important factor emerging from the study.

\section{SUGGESTIONS TO IMPROVE THE PGDHE AT THE UNIVERSITY}

To make professional development programmes more effective, more consistent with the needs of academics, and more integrated with their work, interviewees made the following suggestions:

- Encouraging multiple strategies would be more prudent than mandating a single approach where all academics do the same courses using the same approach of teaching (Participants 3 and 5).

- Embedding more professional development programmes in the University or in the workplace, so that they are more related to the specific work experiences of the academics, rather than continuing with the 'one size fits all' approach adopted by the one of the faculites. Participant 2 commented: 'We need to have access to our colleagues from say our departments and be encouraged to share, discuss and reflect on practices specially relating to our departments, but I am not sure how this can be done’.

- Increasing awareness among university leadership and faculties of the importance of existing professional development opportunities and the alternatives available. Such audiences will need to be convinced that the new forms of professional development programmes are urgently needed to support reforms in standards, curriculum and instruction effectively (Participant 3).

- There is a need to increase support and awareness at the University. Management should be convinced that professional development programmess are necessary and that time and money should be allocated to support the programme which is designed to improve teaching and learning, which are key elements in the university (Participants 2, 4 and 6).

- The professional development programme for academics should focus mainly on problems of teaching and learning. Issues like research, community service and other related university programmes can be addressed in departmental workshops (Participants 7, 8 and 10).

- The programme should support university-wide improvements in teaching and learning, stimulating individual growth and engagement in teaching and supporting career 
development (Participant 9).

- $\quad$ Professional development programmes should be rooted in subject matter and focused on student learning so that they can have a significant impact on student achievement (Participants 2 and 11).

- $\quad$ Effective professional development programmes should be designed so that academics can apply what they learn directly to their teaching. A programme can lead to better instruction and improved learning when it is connected to the curriculum materials academics use and to the assessment and accountability measures that evaluate the success of academics (Participants 5, 9 and 10).

Given the above concerns, I would suggest that professional development programmes should focus on creating spaces for academics to develop and enhance their abilities to design university curricula and facilitate student learning in the Zimbabwean context. Further investment needs to be made in the development of academics and it is through this investment that quality in terms of teaching and learning outcomes can be achieved. Ever-changing information technologies and the profound shift in teaching and learning processes that this technology brings require ongoing support and investment in the professional development of academics.

\section{CONCLUSION}

The changing goals of student learning in higher education, coupled with changing contexts of teaching, has led to a need to provide professional development to sharpen the skills and knowledge of academics. The findings of this study indicated that participants wanted and needed professional development so that they could improve the quality of their own teaching. The PGDHE enabled academics to improve their teaching strategies. As up to 80 per cent of the university curriculum is taught by lecturers who have not undergone teacher education, increased investment in their development as teachers would benefit them, their learners and the University as a whole. Professional development programmes such as the PGDHE are crucial for improving teaching, assessment practices, curriculum design and development and learning support, including the role of information technology in learning and teaching.

There is little doubt that Zimbabwe and the entire SADC region is profoundly affected by a growing international culture of globalisation and by a wide array of cultural, social and economic forces which impact on higher education. Participants in the study acknowledged the positive connection between professional development and teaching quality, especially 
activities that meet external standards set by the bodies responsible for accreditation and the curricula they delivered.

The PGDHE course at NUST, as well as a range of workshops, mentoring programmes and short courses on teaching- and learning-related topics, all contribute to enhancing the teaching competencies of academics. The PGDHE is seen as a central source for training academics in the university. The programme has managed to offer committed academics a place to share ideas, talk about challenges related to teaching and learning, and discover ways of providing one another with continuing support and development in order to enhance learning achievement. The PGDHE provides academics who have no prior training as teachers with the skills required for university-level teaching. Most responses from participants support the findings by Tynan et al. (2012) that academic staff in universities should engage actively in professional development programmes which enable them to achieve high-quality learning outcomes for students. Universities should invest in professional development to improve the teaching competencies of academics. The main challenge that has been experienced in participating in the PGDHE was that attendance by academics was sometimes affected by their regular university teaching duties, to the extent that some of them found it difficult to attending to their teaching loads and also participate in the PGDHE programme.

\section{REFERENCES}

Ballantyne, R., J. Bain and J. Packer. 1999. Researching university teaching in Australia: Themes and issues in academic's reflections. Studies in Higher Education 24(2): 237-257.

Barnard, A., W. Croft, W. Iron, N. Cuffe and W. R. P. Bandara. 2011. Peer partnership to enhance scholarship of teaching: A case study. Higher Education Research and Development 30(4): 435448.

Bernard, H. R. 2002. Research methods in anthropology: Qualitative and quantitative approaches. Walnut Creek, CA: Alta Mira Press.

Borko, H. 2004. Professional development and teacher learning: Mapping the terrain. Educational Research 33(8): 3-15.

Candy, P. 1996. Promoting lifelong learning: Academic developers and the university as a learning organization. The International Journal of Academic Development 1(1): 7-18.

Chalmers, D. and D. Gardiner. 2015. An evaluation framework for identifying the effectiveness and impact of academic teacher development programs. Studies in Educational Evaluation 46: 81-91.

Charmaz, K. 2006. Constructing grounded theory. A practical guide through qualitative research. London: Sage Publishers.

Cox, M. D. and L. Richlin. 2004. Building faculty learning communities. San Francisco: Jossey Bass Publishers.

Creswell, J. W. 2007. Qualitative inquiry and research design. Thousand Oaks: Sage Publishers.

Dewey, J. 1916. Democracy and education. New York: MacMillan.

Doherty, I. 2010. A learning design for engaging academics with online professional development models. Journal of Learning Design 4(1): 1-14. 
Eley, M. 2006. Teachers' conceptions of teaching, and the making of specific decisions in planning to teach. Higher Education 51: 191-214.

Firestone, W. A. and C. Riehl. 2005. A new agenda for research in educational leadership. New York: Teachers College Press.

Gay, L. R., G. E. Mills and P. Airasia. 2012. Educational research: Competencies for analysis and applications. Boston: Pearson Publishers.

Gibbs, G. and M. Coffey. 2004. The impact of training of university teachers on their teaching skills, their approach to teaching and the approach to learning of their students. Active learning in Higher Education 5(87): 87-100.

Gosling, D. 2001. What educational developers do. Five years on. International Journal for Academic Development 6(1): 74-92.

Gosling, D. 2008. Educational development in the United Kingdom. Report for the Heads of Educational Development group. London: HEDG UK. http://www.ledg.ac.uk/docunments/ HEDG_Report_Final.pdf (accessed 5 June 2015).

Gosling, D. and K. O’Connor. 2006. From peer observation of teaching to review of professional practice (RPP): A model for continuing professional development. Educational Developments 7(3): $1-4$.

Guskey, T. R. 1986. Staff development and the practice of teacher change. Educational Research 15(5): $5-12$.

Guskey, T. R. 1997. Research needs to link professional development and student learning. Journal of Staff Development 18(2): 36-40.

Guskey, T. R. 2000. Evaluating professional development. Thousand Oaks, C.A: Corwin Press.

Guskey, T. R. 2002. Professional development and teacher change. Teachers and Teaching: Theory and practice 8 : 381-391.

Higgins, K. and R. E. Harreveld. 2013. Professional development and the university casual Academic: Integration and support strategies for distance education. Distance Education 34(2): 189-200

Hossain, J. 2010. Professional development of higher education teachers: Can ODC contribute? Turkish Journal of Distance Education 11: 122-132.

Hunzicker, J. L. 2011. Effective professional development for teachers: A check-list. Professional Development in Education 37: 177-179.

Kreber, C. and P. Brook. 2001. Impact evaluation of educational development programs. International Journal for Academic Development 6(2): 96-108.

Ling, P. 2009. Development of academics and higher education futures. Sydney: ALTC Publishers.

Locks-Horsley, S., N. Love, K. E. Stiles, S. Mundry and P. W. Hewson. 2003. Designing professional development for teachers of Science and Mathematics. Thousand Oaks, CA: Corwin Press.

McLaughlin, M. W. and J. Talbert. 2006. Building school-based teacher learning communities: Professional strategies to improve student achievement. New York: Teachers College Press.

McWillian, E. 2002. Against professional development. Educational Psychology and Theory 34: 289299.

Meiers, M. and L. Ingvarson. 2003. Investigating the links between teacher professional development and student learning outcomes. (Vol 1). Canberra: ACER.

Moon, J. 2004. Using reflective learning to improve the impact of short courses and workshops. Journal of Continuing Education in the Health Professions 24(1): 4-11.

Morse, J. M. 1991. Qualitative nursing research. London: Sage Publishers.

Mukeredzi, T. G. 2013. The journey to becoming teaching professionals in rural South Africa and Zimbabwe. Australian Journal of Teacher Education 38(10): 83-104.

Patton, M. Q. 2001. Qualitative evaluation and research methods. London: Sage Publishers. 
Roxå, T. and K. Mårtensson. 2008. Strategic educational development. A national Swedish initiative to support change in higher education. Higher Education Research and Development 27(2): 155168.

Rust, C. 2000. Do initial training courses have an impact on university teaching? The evidence from two evaluative studies of one course. Innovations in Education and Teaching International 37(3): 254-262.

Silverman, D. 2014. Interpreting qualitative data. Singapore: Sage Publishers.

Stake, R. E. 2005. Qualitative case study. In The Sage handbook of qualitative research, ed. N. K. Denzin and Y. S. Lincoln, 450-451. $3^{\text {rd }}$ ed. Thousand Oaks, CA: Sage Publications.

Stefani, L. and L. Elton. 2002. Continuing professional development of academics teaching through self-initiated learning. Assessment and Evaluation in Higher Education 27(2): 117-129.

Tynan, B., Y. Ryan, L. Hinton and M. A. Lamont. 2012. Out of hours. Final report of the project eteaching: Planning and implementing a benefits-oriented costs model for technology-enhanced learning. Canberra: Department of Education, Employment and Workplace Relations and Australian Learning and Teaching Council.

Weiss, I. R. and J. D. Pasley. 2006. Scaling up instructional improvement through teacher professional development: Insights from the local systematic change initiative. (PRE Policy Brief No RB-44). Philadelphia: Consortium for Policy Research in Education.

Yoon, K. S., T. Duncan, S. W. Lee, B. Scarloss and K. L. Shapley. 2007. Reviewing the evidence on how teacher professional development affects student achievement. Washington DC: National Center for Education Evaluation and Regional Assistance, Institute of Education Sciences, US Department of Education. 
Appendix A

\section{CORE MODULES FOR THE PGDHE PROGRAMME}

\section{Semester 1:}

- Scholarship in higher education

- Learning and teaching strategies in higher education

- Programme planning and development.

\section{Semester 2:}

- Student assessment in higher education

- Understanding adolescents and mature students

- Educational and information technology

\section{ELECTIVE MODULES}

Candidates select three modules per semester from the following list:

\section{Semester 1:}

- Large and small group teaching

- $\quad$ Problem based learning

- Quality and innovation in higher education

- Improving students research and design projects

- Academic involvement in the community.

\section{Semester 2:}

- Policy, professionalism and management

- Higher education curriculum development

- Strategic planning, leadership and governance

- Statistics for educators

- Research, consultancy and publishing. 